\title{
走査電子顕微鏡による唾石の観察
}

倉地洋一・松本英彦・南雲正男

榎本昭二・滝口励司*

\section{Scanning electron microscopic study of the salivary calculi}

\author{
Yoichi Kurachi - Hidehiko Mathumoto - Masao Nagumo \\ Shoji Enomoto $\cdot$ Reiji TAKIguchi*
}

緒

言

唾石症は，唾液腺あるいはその導管の中に結石形成を 伴ら疾患で, 臨床的には食物摂取時の腫脹と喠仙痛が特 改的な症状である。醀石の成因については，今まで種々 の方法で検索がなされてきたが，いまた明確な結論を出 すに至っていない上らである。硳石の構造に関する形態 学的な面からの検索として, 偏光, 金属, 光学顕微鏡に よる観察がなされている ${ }^{1,2)}$. 最近では電子顕微鏡によ る観察 ${ }^{3)}$ も行われているが，走査電子顕微鏡を用いての 詳細な観察4 6) は少ないよらである.今回われわれは， 䫟下腺管内唾石 7 症例について, 割面ならびに表面構造 を走查電子顕微鏡を用いて観察し，あわせて同一唾石に ついてェネルギー分散型X線分析計による元素分析を行 い，唾石の成因に関する若干の知見が得られたので，そ の概要を報告する。

\section{研究材料および方法}

\section{1. 観察症例}

観察した唯石は，表 1 のごとく昭和大学歯科病院第 2 口腔外科で経験した 7 症例であり,すべて䫇下腺ワルト 管内のもので, 大きさは直径 $1 \mathrm{~mm}$ 前後から, 最大 径 $8 \mathrm{~mm}$ であった。

昭和大学歯学部第 2 口腔外科学教室（主任：榎本 昭二教授)

* 昭和大学透学部第 1 口腔解剖学教室（主任：㜔口 励司教授)

The Second Department of Oral Surgery, School of Dentistry, Showa University (Chief: Prof. Shoji Enomoto)

* The First Department of Oral Anatomy, School of Dentistry, Showa University (Chief: Prof. Reiji Takiguchi)

受付日：昭和55年 4 月 24 日
表 1 観察症例

\begin{tabular}{|c|c|c|c|c|c|}
\hline 症例 & 年齢 & 性 & 部 位 & 大きさ & \begin{tabular}{|l} 
割面, \\
核の有無
\end{tabular} \\
\hline 1 & 36 & 男 & 左顎下腺管内 & $6 \times 5 \times 5 \mathrm{~mm}$ & 1 核 \\
\hline 2 & 52 & 女 & 右顎下腺管内 & $3 \times 2 \times 3 \mathrm{~mm}$ & 無 \\
\hline 3 & 22 & 女 & 左顎下腺管:内 & $8 \times 6 \times 6 \mathrm{~mm}$ & 2 核 \\
\hline 4 & 52 & 女 & 右顎下腺管内 & $7 \times 7 \times 5 \mathrm{~mm}$ & 1 核 \\
\hline 5 & 42 & 男 & 左顎下腺管内 & $5 \times 6 \times 5 \mathrm{~mm}$ & 1 核 \\
\hline 6 & 46 & 女 & 左靧下腺管内 & $\phi 1 \mathrm{~mm}$ 以下数個 & 無 \\
\hline 7 & 8 & 女 & 左靧下腺管内 & $2 \times 2 \times 2 \mathrm{~mm}$ & 無 \\
\hline
\end{tabular}

\section{2. 観察方法}

ワルトン管内より摘出した唾石は，2.5\% glutar al一 dehyde 溶液（リン酸緩衙液 $\mathrm{pH}$ 7.4）で 3 時間固定, $4 \% \mathrm{NaOCl}$ 溶液中に10分間浸漬して軟組織を可及的 に除去し, 蒸留水にて洗浄後, アルコール系列にて脱 水, 凍結割断し, 自然乾燥, カーボン蒸着し, 日立X 560 型微小部走査 $\mathrm{X}$ 線分析装置に, Kevex 7000 型エネル ギー分散型X線分析装置を取りつけた装置を使用して, 走査電顕像を観察し, 同時に点分析法により含有元素の 特性X線を検出した。 また, 一部の試料は, 臨界点乾 蜗, 白金蒸着後, 明石 MSM 102 型走査電子顕微鏡任 て観察した.

\section{観 察 所 見}

\section{1. 割面構造}

割面構造で, 中心に核㥞構造を有する症例が 7 例中 4 例（症例 1，3，4，5）で, 他の 3 例には核様構造が みられなかった，症例 3 は2 核を有していた（図 1 ).

核を有する症例の割面像は，全体としては同心円状の 層状構造を示し, 次の 3 つの部分に分けることができ る.すなわち, 中心核部, 層状楧造部, 最表層部である (図 2). 


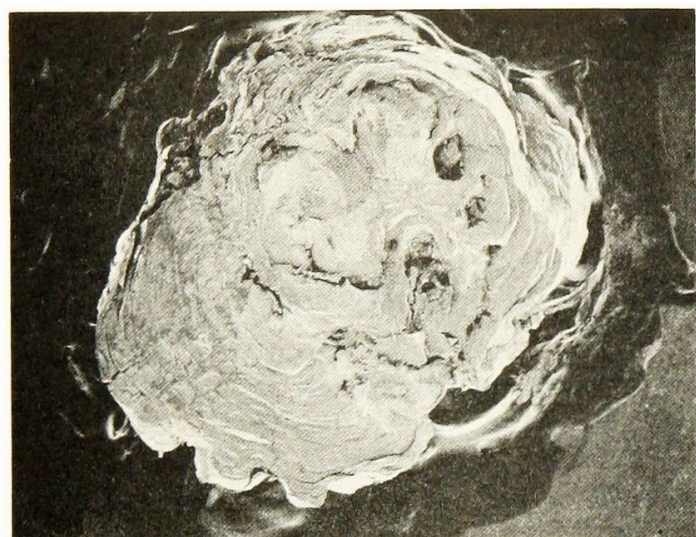

図 12 核を有する呼石の割面像 $(\times 10)$

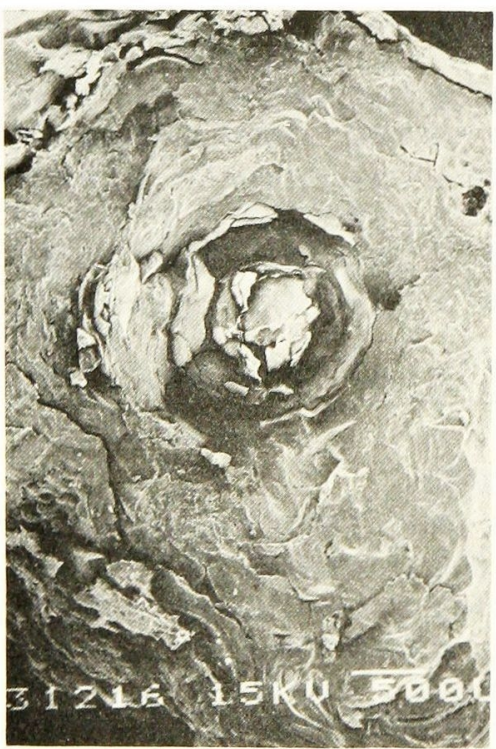

図 2 割面の全体像 $(\times 20)$

中心核の割面像は多様であるが，一般には均犋な塊状 緻密な物質でしぬられており，直径 $1 \mu$ 前後の球形の顆 粒状構造が多数融合し，大きさ不定の顆粒塊を形成して いた（図 3，4）.針状結晶様構造が集合している像む钼 察されたまた，一部の症例では球形の有機物質を思わ せる像や，桿状满造を呈する像も観 察された（図 5 ， 6).

中心核の辺縁では，わずかな空隙が認められ，その外 層は層状構造物でとり用まれていた，各懕は一様ではな いが，その厚さは注涪一定の幅で中心核をとりまいてい た(图 7). 層状棈造を強拡大でみると, 直径 $1 \mu$ 前後 の小顆粒が密に螱合して層板を形成しており，各層の間 には間纱が認められた，割断面では，小顆粒が密に融合 した部分と粗な顆粒部分とが交互に配列していた（図

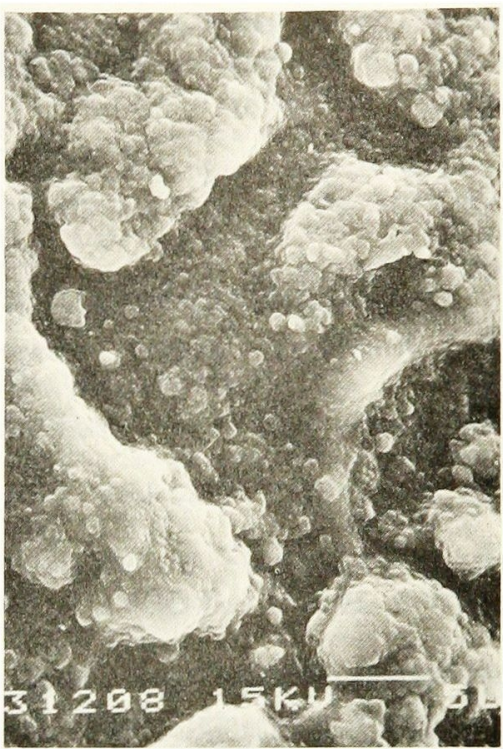

图 3 中心核部 $(\times 3,000)$

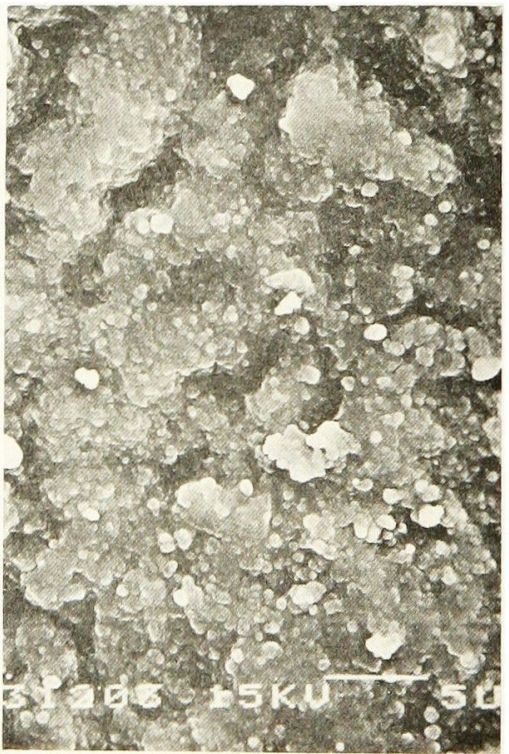

図 4 中心核部 $(\times 3,000)$

8).

層状檴造部の外㬝は無構造で（図 9），強払大でみる と多くは顆粒状結晶, 板状結晶等の均質, 緻密な像を示 していた（図10）.

中心核が認められない唾石剨面は，小顆粒状や針状の 結晶棁棈造物方比渎的均質に，放射状や渦巻状に配列し た像が観察された（図11）. また一部の症例では, 桿状, 系状構造物が網目状に配列した像が観察された（図12）. 


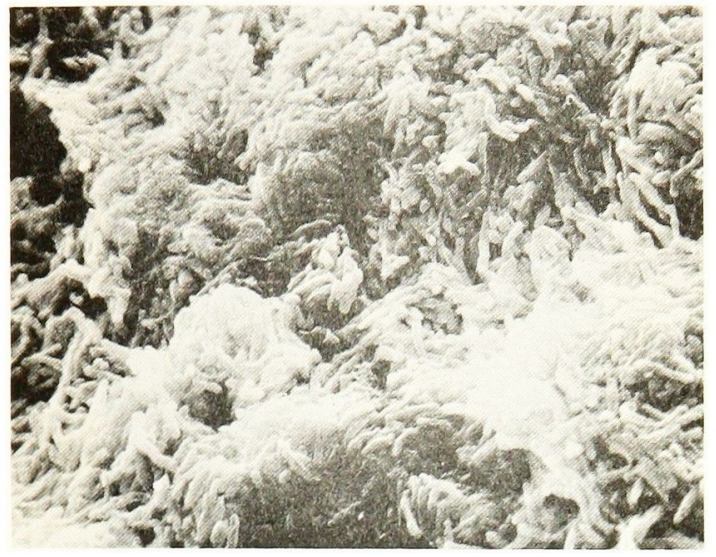

図 5 中心核の割面構造 $(\times 2,000)$

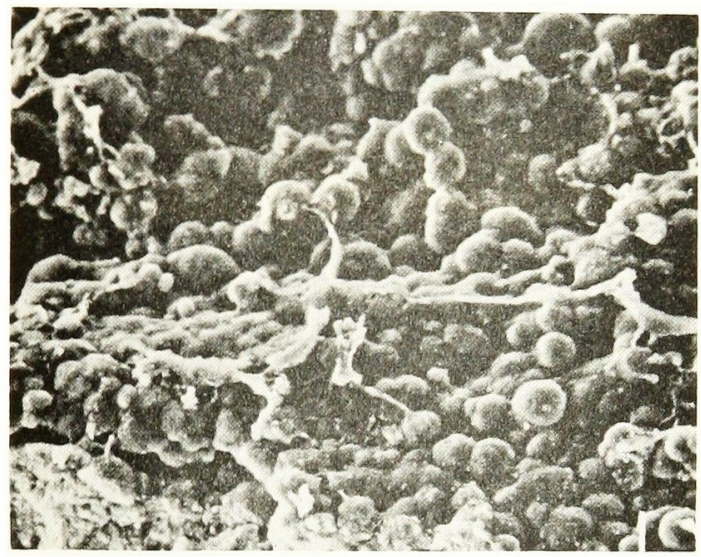

図 6 中心核の割面像 $(\times 1,100)$

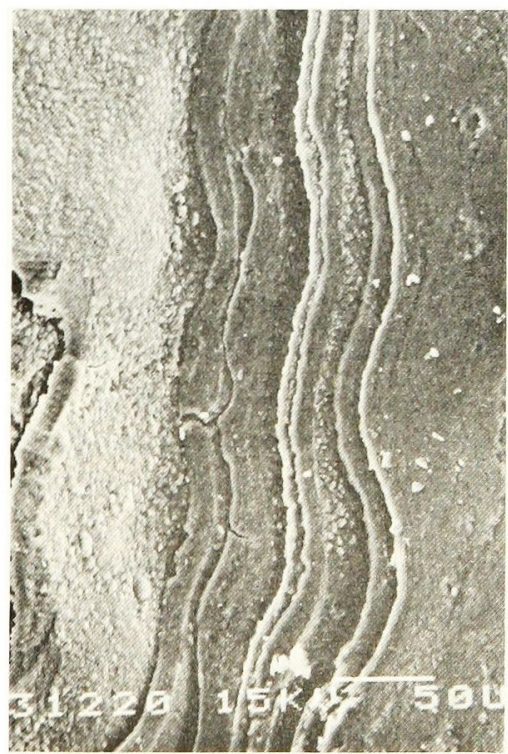

图 7 層状搆造部 $(\times 300)$

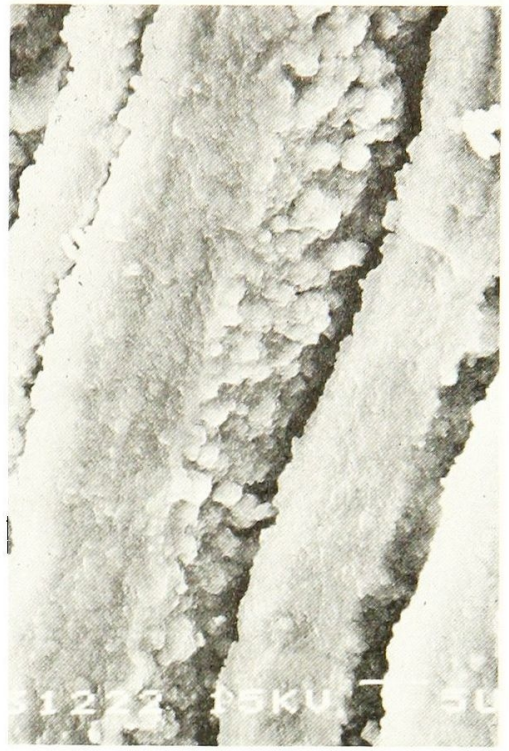

図8図7 の桩大像 $(\times 2,000)$

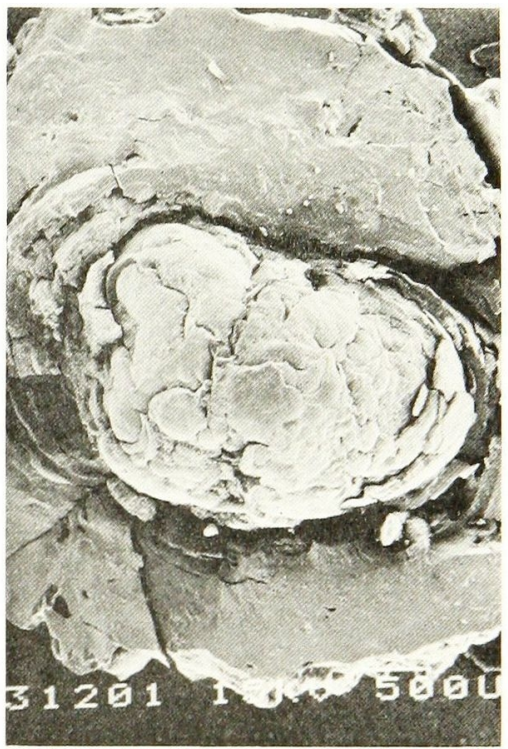

図 9 割面像，層状構造部の外層は無 構造にみえる $(\times 20)$

\section{2. 表面構造}

唾石の表面構造は粗な顆粒状を呈しており, 顆粒は大 きさ $5 \sim 10 \mu$ の比較的輪郭が明膫なるのから, 融合し て大きな塊を形成しているるのまで種々であった，多く は表面に凹凸があり，小さな顆粒が成長し，あるい以融 合していく過程と思わせる像を示していた（図13，14）. また，一部では有機物を思わせる系状構造物が観察され た. 


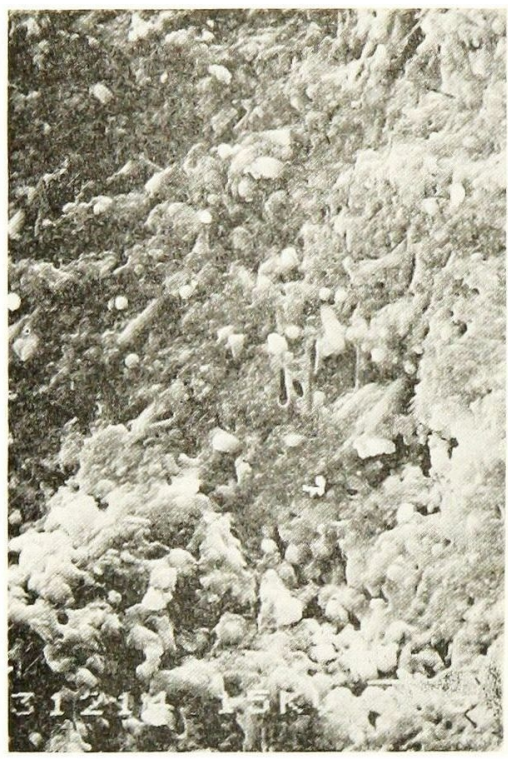

図 10 無構造部の摭大 $(\times 2,000)$

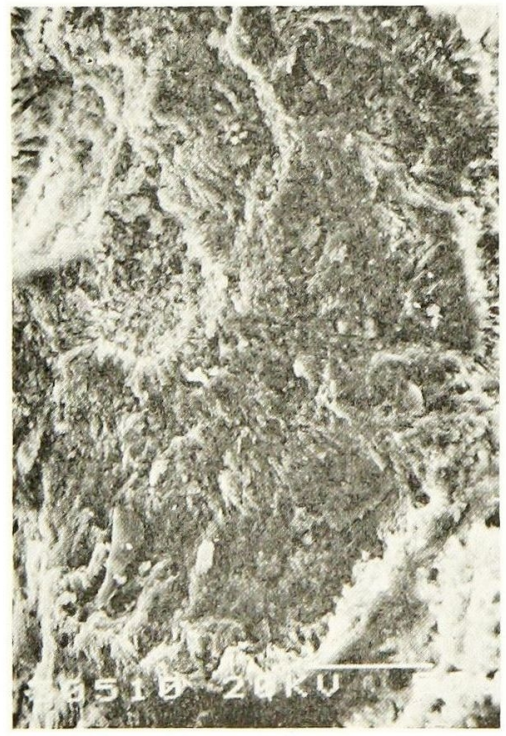

图 11 核梅造のない症例の割面像 $(\times 2,000)$

3. X線マイクロアナライザーによる元素分析結果 中心核部の元素分析の結果では， $\mathrm{Ca} ， \mathrm{P}$ が 全例に検 出され，多くの症例に $\mathrm{S}$ 子検出された（図15）.

層状構造部の元素分析結果では，中心部とほぼ同様に $\mathrm{Ca}, \mathrm{P}$ が大部分をしめていた（图16）.

表面の元素分析結果では， $\mathrm{Ca}, \mathrm{P}, \mathrm{S}$ を主体飞, $\mathrm{Mg}$, $\mathrm{Si}, \mathrm{Cl}, \mathrm{Zn}, \mathrm{Cu}$ 等の各種多様の元素が 検出された（図 17).

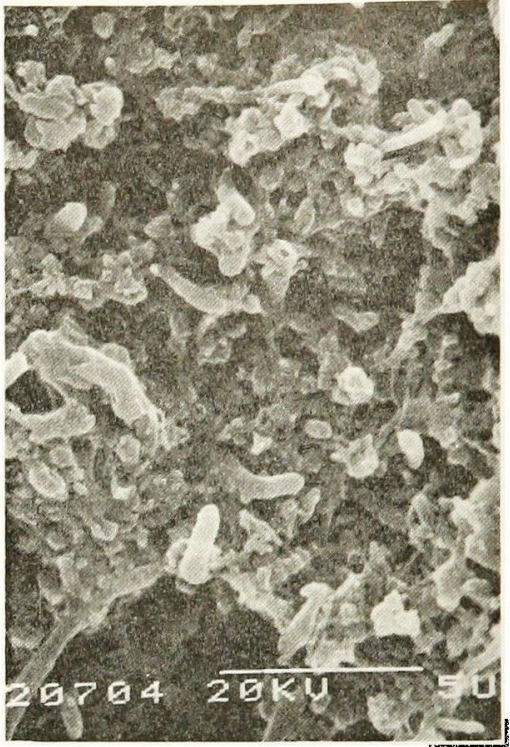

図 12 区11の一部強拡大像 $(\times 6,000)$

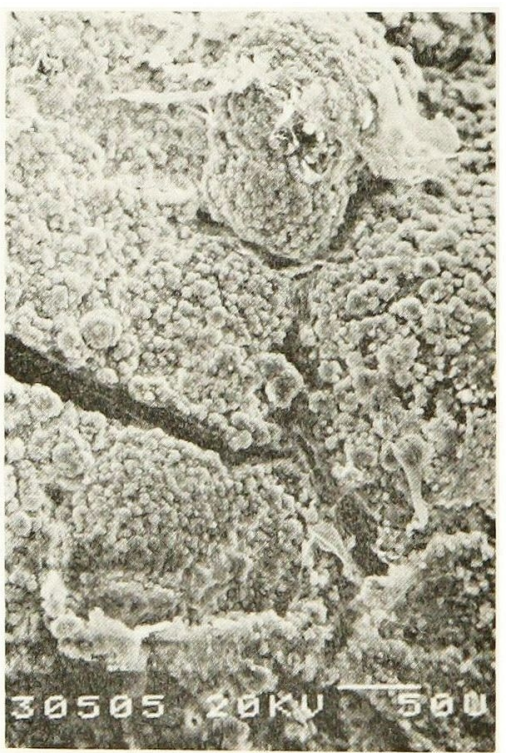

図 13 表面粰造 $(\times 200)$

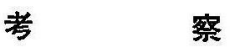

唾石症は，日常臨床でしばしば遭遇する疾患であり， 好発部位は顎下腺および顎下腺管で，耳下腺，舌下腺で の発生は少ないよらである7)。これは唾液腺の解剖学的 形態と唾液の性状によるものとされている4．すなわ ち, 舌下腺は排出管が短く，唾夜が停滿しにくいと考党 られ，耳下腺は傣液腺であることから呼石ができにくい 


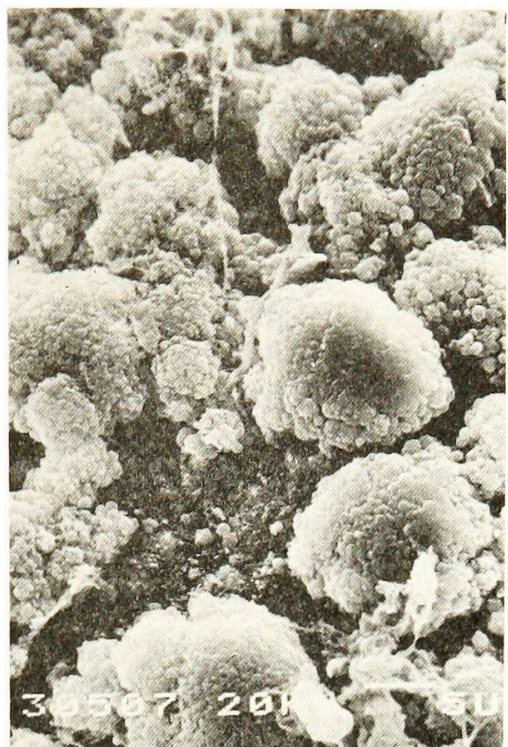

図 14：図13の抬大像 $(\times 2,000)$

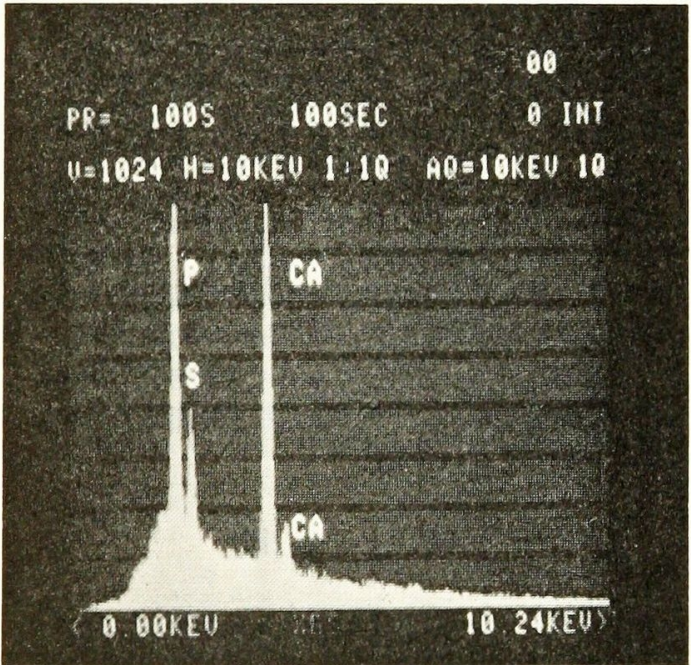

図 15 中心核部のX線マイクロフナライザーの結 果

と考兄られる。顥下腺に結石形成が多い理由として，1) 顎下腺の排出管は耳下腺の排出管に比べて長いこと，2) 顥下腺の唾液排出は重力に逆らって下方から上方になる こと.3）顎下腺由来の唾液はアルカリ性が高いこと.

4) 顎下腺には粘液腺成分が多いことなどがあげられて いる4). 今回のわれわれの観察正例もすべて顎下腺ワル トン管内のむのであった.

唾石の成因について今日まで種々な方法 1 18) で検索さ れてきたが，いまだ確定した結論を得るに至っていな い. 構造に関する形態学的方面の検索として， 偏光 ${ }^{1)}$,

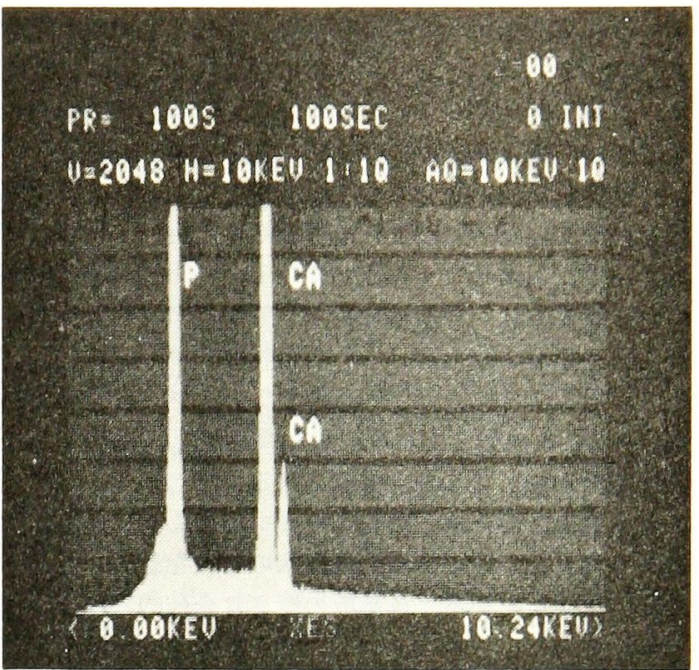

図 16 層状構造部のX線マイクロアナライザーの 結果

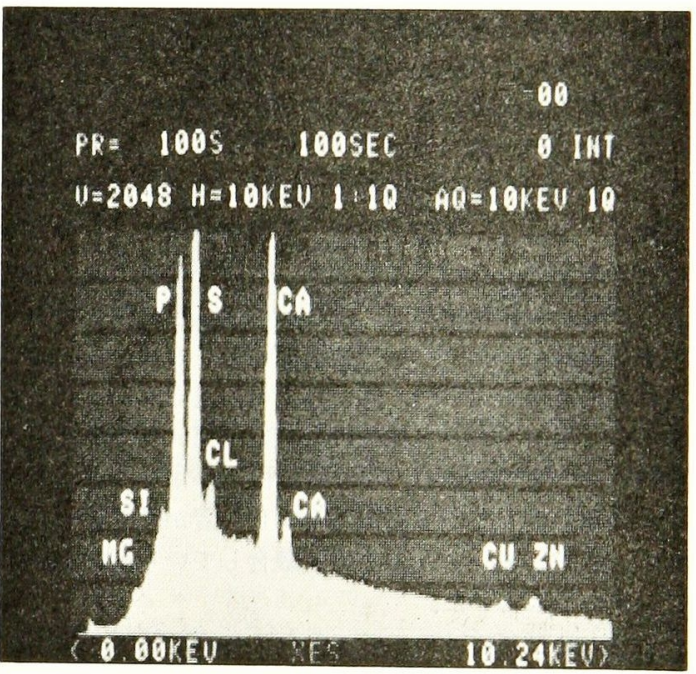

図 17 表面のX線マイクロアナライザーの結果

金属，光学顕微鏡 ${ }^{2)}$ による観察や電子顕微鏡による超微 細構造の観察 ${ }^{3 \sim 6}$ 19,20) る行われているが，成因を解明す るに至っていない.

今回われわれは走查電子顕微鏡を用いて，唾石の割 面，特よび表面の微細構造を観察したが，その割面像で は，浪中央部に核様構造を持つ症例が 4 例で，核様構 造のないものが 3 例であった。向山涹は唾石には必ず 1 個の核が存在し，その位置は中央部ではなく偏在してい ると報告し，多くの報告者す大部分の症例に核様構造を 認めている。われわれの症例では，直径 $3 \mathrm{~mm}$ 以下の 小さな唾石には核様構造が認められて拉らず，一定の大 きさ以上に成長しないと核様構造は生じないと思われ 
る. 核様構造を示す症例の割面は，全体として同心円状 の層状構造を示しており，大きく中心核部，層状構造 部，最表層部に区別することがでさる，中心核の構造の 多くは，均質な塊状緻密な物質であったが，直径 $1 \mu$ 前 後の顆粒状結晶の融合や針状結晶構造もみられ，多様な 像を呈していた。 このよらな所見は平出ら $5^{4)}$, 川端ら5), 森永 ${ }^{19)}$ ，松本 $5^{20)}$ 女報告している。中心核の中に細菌 を思わせる系状, 桿状構造物や，線維性の有機物を思わ せる像が観察されたが，これらの物質が核形成の一因と なり，そこに $\mathrm{Ca}, \mathrm{P}$ の沈着が起こり，さらにその周囲 に $\mathrm{Ca}, \mathrm{P}$ を主体とした顆粒状物質が沈着, 融合し, 唾 石が增大していくものと推測される。

中心核の外層には，核をとりまいて同心円状の層状構 造がみられたが、この構造は樹木の年輪を思わせるよう な配列を示している．各層板の厚さは全体的にほぽ一定 の幅を持っているが，おの扐のの層板の厚さは多少異な っており，唾石の成長過程が一様でないことを示してい るものと思われた。層状構造部を強抎大で観察すると， 直径 $1 \mu$ 前後の小顆粒が密に融合した部分と，粗な顆粒 部分とが交互に配列して，層状構造を形成しているよう にみられた。この層板構造について梶山到は，石灰化度 の低い部分と高い部分により，交互に構築されて層状を 形成するものと述べている.

中心核のない唾石の割面構造は，比較的均質な小顆粒 状結晶の集合で, 一部に桿状, 系状構造物がみられ, 中 心核の割面構造と類似しており，唾石が初期のもので， さらに唾石が成長すれば, 中心核になる可能性があるも のと思われた。

表面構造は平出 $5^{4)}$, 森永 $5^{199}$ の所見と同様に, 粗な 顆粒状を呈しており，顆粒の大きさは種々で，表面の状 態もさまざまであった，多くは表面に小さな凹凸がみら れ，顆粒の接している周辺部位から沈着が繰り返し行わ れて, 顆粒が成長し, あるいは融合していく過程を思わ せる像を呈していた。

唾石の化学組成は無機質が $80 \%$ 内外をしめ, その主体 はリン酸カルシウム $(70 \%)$ と，炭酸カルシウム $(10 \%)$ で微量の金属子含み，有機質としてはムコ多糖類，尿

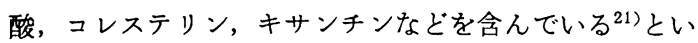
われている. 今回のX線マイクロフナライザーの元素分 析結果では， $\mathrm{Ca} ， \mathrm{P}$ が主体に検出され，その分布はほ ぼ均一であった，多くの症例に $\mathrm{S}$ 子検出されている．表 面では, $\mathrm{Mg}, \mathrm{Si}, \mathrm{Cl}, \mathrm{Zn}, \mathrm{Cu}$ 等の各種多数の元素が検出 されており，喠石表面に付着した物質によるものと思わ れる. 今後これらの元素の定量分析を行えば, さらに唾 石の化学組成が解明されるものと思われる.

無機質の結晶構造については, 以前よりX線回折, 赤 外線分析および熱分析などの方法により分析されてお ク, 岡田 ${ }^{13,14)}$, 梶山2), Blatt $ら^{22)}$ はX線回折の結果から, 結晶成分はほとんど hydroxyapatite であると報告して

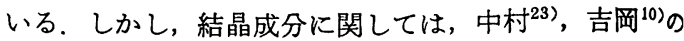
tricalciumphosphate, Jensen $ら^{11)} の$ whitelockite, 福田 ${ }^{15}$ ) および金沢ら ${ }^{24)} の$ hydroxapatite と whitelockite, の両 方が含まれるとする報告など一致していない，これはお もに喠石の結晶性の低さからくる解析の困難さが原因》 と考えられている.

金沢ら ${ }^{24)}$ は有機質組成を検討し，顎下腺唾液の蛋白 組成が proline に富む特徽的なパターンを示すのに対 し, 唾石では proline は少なく, glutamic acid pasparaginic acid などの酸性アミノ酸が多い特徵を示して おり，唾液中の蛋白質の特定成分か，唾石構成に関与し ているとの興味ある報告をしている.

唾石の成因に関しては，炎症説，異物説，細菌説，外 甥説, 体質説, 内分泌説, 唾液貯留説などの原因が考兄 られているが，定説はないようである ${ }^{4,25)}$. 池田 ${ }^{26)}$ は炎 症が第一次的原因であると述べ, 炎症の結果組織の浮嗹, 上皮細胞の剝脱ならびにこれに伴い有機物の沈着をきた し, 石灰塩類の沈殿を起こすためと述べている. 石川 ${ }^{21}$ は分泌液のコロイド溶液状態に異常が起こり, 無機質が 析出してくるもので, 唾液の化学的性状の変化, 唾夜の 停滞，局所の炎症などが原因となると述べている。一般 には，核芯となるべき固形物体の存在と，炎症による 唾液の性状の変化の二元説が 支持されているようであ る ${ }^{4)}$ Pratt ${ }^{27}$ によれば, 歯ブラシの毛, 松葉, 草葉, 小 麦の穂, 魚骨, 爪などを異物として報告している，今回 観察した症例では, 細菌を思わせる構造物や，線維性の 有機物を思わせる像が観察されており，これらが核形成 の一因となり, そこに $\mathrm{Ca}, \mathrm{P}$ の沈着が起こり, さらに その周囲に $\mathrm{Ca}, \mathrm{P}$ を主体とした顆粒状物質が沈着, 癌 合し, 唾石が增大していったものと推測される過程が， 形態的に観察された。 今後さらに症例を追加して検索す る必要があると思われる。

$$
\text { 結語 }
$$

㴿下腺ワルトン管内から摘出した㕰石 7 症 例につい て, 走査電子顕微鏡を用いて割面ならびに表面の構造を 観察し，あわせて同一唾石について，エネルギー分散型 $\mathrm{X}$ 線分析計による元素分析を行い，次のような結果を得 た.

1. 唾石割面では核様構造を有する症例 4 例で，全体 的に層状構造をなし，中心核部，層状構造部，最表風部 に区別することができた。

2. 中心核部には細菌を思わせるような，系状構造物 や線維性の有機物を思わせる像が観察され，これらが核 形成の一因になるものと推測された。

3. 表面構造は粗な顆粒状を呈し，小さな顆粒が成長 し，あるいは融合していく過程を思わせる像を示してい た. 
4. X線マイクロアナライザーの元素分析結果では, $\mathrm{Ca}, \mathrm{P}$ が主体に検出され，その分柧はほぼ均一であっ た.

本論文の要旨の一部は, 第33回日本口腔科学会総会に 扣いて発表した。

\section{引用文 献}

1）原田一：偏光顕微鏡による四石の光学的研 究。㐘科月報 19：581 1939 .

2) 暒山稔：唾石の構造に関する研究。九蔽会誌 20: 1431963.

3) Anneroth, G., et al.: Ultrastructure of salivary calculi. Scand J Dent Res 86: 182 1978.

4) 平出文彦, 他：唾石の形態学的钼察。耳喉 50: 2411978.

5）川端五十鉿，他：唾石の走査電顕像。耳鼻と臨 床 21: 681975 .

6）亀山忠光, 他：自然排出した大きな唾石症の 1 例。口科誌 28：269 1979 .

7）原利通，他：唾石症の臨床統計的および病理 組織学的観察。日口外誌 25：1066 1979.

8）鈴木忠彦：X線結晶解析法に上る唾石内結晶成 分の研究。臨床莼科 1：575 1939.

9）鈴木忠彦：唾液腺のレ線学的研究。臨林菌科 12: 4231940.

10）吉岡新一：X線回折，X線螢光分析ならびに分 光分析による唾石の結晶構造扣よび含有微量金 属の检出についての研究。日本体質学雑誌 23 : 2301958.

11) Jensen, A.T., et al.: X-Ray crystallographie examination of calcium from salivary glands.
J Dent R 31: 6201952.

12）伴 長敬：整石の光学的分析について，京大口 科紀要 1: 371959.

13）岡田充弘：生体内結石の $\mathrm{X}$ 線回折(第 1 報). 日 口外誌 7: 1131961.

14）岡田充弘: 生体内結石の X線回折 (第 2 報). 日口外誌 8: 11962 .

15）福田健：人烸石の性状に関する物理化学的研 究. 阪大绦学誌 12: 2351963.

16) Anneroth, G., et al.: Morphology of salivary calculi. J Oral Path 4: 2571975.

17) Anneroth, G., et al.: Crystalline structure of salivary calculi. J Oral Path 4: 2661975.

18）向山正秋：唾石の敝造とその形成経過に就い て。菌科学報 48: 688 1955 .

19）森永 太, 他：走査電子顕媺鏡に上る唾石症の 睍察。口科誌 25：594 1976.

20）松本康博，他：走査電顕に上る唾石の钼察。口 科誌 28：703 1979 .

21) 石川梧郎, 秋吉正豊: 口腔病理学II. 永末毒 店, 京都, 1975,880頁.

22) Blatt, I.M., et al.: Studies in sialolithiasis. Ann Otol Rhinol Laryngol 67: 5951958.

23）中村博司：透石と唾石との硬組織の組成に関す 万物理化学的比較研究。俻科医学 25：246 1962.

24）金沢拓美，他：異所石灰化組織の有機基質につ いて。骨代謝 12：434 1979 .

25）增田 守：顎下腺管内唾石の 3 症例並びにその 機器分析結果について。耳鼠 18：249 1972.

26）池田裕彦：顎下腺組織と唾石症。日耳舆 62: 5951959.

27) Pratt, L.W.: Foreign body of Wharton's duct with calculus formation. Am Otol 77: 88 1968. 